\title{
Electron Microscopical Observations on the \\ Formation of Yeast-mitochondria
}

\author{
by Masako Osumi*
}

Received February 24, 1965

Since the discovery of mitochondria as distinct intracellular particles, the origin and biogenesis of mitochondria have been an interesting problem to study. Especially, according to the development of electron microscopy, the structure of mitochondria has been studied with connection to their function and to the interpretation of their molecular organization. ${ }^{1-8)}$ Recently, some reports on the relation between the structure and function of yeast-mitochondria were published, and the investigators tried to make the origin of yeast-mitochondria clear. ${ }^{9-17)}$

During the growth phase, there is parallel relation between the evolution of mitochondrial structure and respiratory activity. During the logarithmic phase, the concentration of glucose decreases and ethanol is formed. At this time the activity of respiration is poor, but during the transitional period between the logarithmic phase and the stationary phase, high respiration rate of the culture is recovered. If the yeast grows in the ethanol-containing medium, the formation of mitochondria would be more progressive. So, ethanol agar media were used and the changes of formation of yeast-mitochondria were observed. Also the development of yeastmitochondria was investigated in aerobic culture, after the cells were cultured anaerobically. Furthermore, the formation of yeast-mitochondria was observed with grown cells on ergosterol-containing medium to confirm the effect of ergosterol on the membrane formation. From these experiments, the origin of yeast-mitochondria were presumed.

\section{Materials and Methods}

Maintenance and growth of yeast. Haploid strain of Saccharomyces No. 24843 (Lindegren's Carbondale Breeding Stock) was used in the present work. The organism was maintained aerobically on agar slopes, "containing (per liter), $20 \mathrm{~g}$ of glucose, $3.5 \mathrm{~g}$ of Difco pepton, $2.0 \mathrm{~g}$ of $\mathrm{KH}_{2} \mathrm{PO}_{4}, 1.0 \mathrm{~g}$ of $\mathrm{MgSO}_{4} \cdot 7 \mathrm{H}_{2} \mathrm{O}, 2.0 \mathrm{~g}$ of $\left(\mathrm{NH}_{4}\right)_{2} \mathrm{SO}_{4}$, and $5.0 \mathrm{~g}$ of Difco yeast extract. The yeast was made to grow for 48 hours at $30^{\circ}$ and subcultured monthly.

Growth of cells on agar slope. The above-mentioned medium was modified for the agar slope culture of the yeast, in which the percentage of glucose was as follows.

$\begin{array}{lccc}\quad \text { Medium } & \text { Broth* } & 4 \% \text { glucose } & 4 \% \text { ethanol } \\ \text { No. } 1 \text { (2\% glucose) } & 50 & 50 & - \\ \text { No. } 2 \text { (1\% glucose }+1 \% \text { ethanol }) & 50 & 25 & 25 \\ \text { No. } 3 \text { (2\% ethanol) } & 50 & - & 50\end{array}$

* Broth contains same chemicals as the above-mentioned medium except glucose which was dissolved in $500 \mathrm{~m} l$ dist. water.

* Department of Biology, Faculty of Home Economics, Japan Women's University, Tokyo, Japan. 
The inoculum of yeast was made in this medium after preculture for 24 hours. The yeast was harvested after $6,12,24$ hours or $2,4,7,14,30$ days.

Growth of aerobic cells in liquid medium. The media for the liquid culture of the yeast were modified No. 1 and No. 3 which contain no agar (No. $1^{\prime}$ and No. $3^{\prime}$ ), and complete-synthetic medium (No. 4), ${ }^{18}$ and ergosterol-containing medium (140 mg ergosterol in $14 \mathrm{~m} l$ of Tween 80 and $19 \mathrm{ml}$ of ethanol, No. 5). The yeast was inoculated on these media after anaerobic growth and was harvested after aeration for $0.5,1,2,4.5$ or 24 hours.

Growth of anaerobic cells. Media used for anaerobic growth were the same as those of aerobic growth except No. 3'. Fieser's solution $(60 \mathrm{~g}$ of $\mathrm{KOH}, 2 \mathrm{~g}$ of sodiumanthraquinone $\beta$-sulfonate and $15 \mathrm{~g}$ of sodiumhydrosulfite in $100 \mathrm{ml}$ of dist. water) was used for this growth and the yeast was incubated in $10 \mathrm{~mm}$ oxygen-free vacuum at $30^{\circ}$. The cells were kept for 2 hours at $0^{\circ}$ before' harvesting, and were washed two times at about $2^{\circ}$ with ice-cold water.

Preparation of cells for electron microscopy. The cells were washed 2 or 3 times with changes of distilled water and then fixed in $1 \%$ aqueous potassium permanganate for 4 to 22 hours at $4^{\circ}$ and subjected to a post-fixation treatment with $1.5 \%$ uranyl acetate in aqueous solution for 1 hour at $4^{\circ}$. After dehydration by serial passage into alchohol or aceton, the specimens were embedded in methacrylate or Epon 812 mixture. Ultrathin sections were made with a JUM-5 ultramicrotome equipped with a glass knife. Sections were picked up on collodion-coated or carbon-coated grids and were examined by an JEM-6A and JEM-T6S electron microscope using $30 \mu$ objective aparture. Electron micrographs were taken at initial magnification of $\times$ 10,000 to 20,000 . The sections were sometimes stained with uranyl acetate or lead nitrate.

Reading of electron micrographs. The number of mitochondria in various growth phases was counted by electron micrographs. The mitochondria were classified into three types(Fig. 1). 30 cells were picked up at random from electron micrographs in each growth phase. The cells in which each type of mitochondria appeared were counted. The number of mitochondria of the three types was counted in each cell and was calculated with the average number per section of cell. The appearance of endoplasmic reticulum-like structure (ERS) and three types of mitochondria were observed in young cells.

Measurement of oxygen-absorption activity. Yeast-cells were suspended in a medium containing $2 \%$ glucose, $M / 40$ succinic acid and $M / 60$ phosphate buffer (pH 5.0), and kept at $30^{\circ}$ to equilibrate the temperature. The oxygen-absorption was measured for 10 minutes polarographically using Clark Oxygen Electrode.

\section{Results}

Development of yeast-mitochondria. In the cells grown for 6 hours in No. 1 medium (Plate VI, Fig. 1), double membraned particles, about $0.1 \mu$ in diameter, were observed, and some of them have the inner membranes infolding into the matrix. After 12 hours, besides the above-mentioned particles, a few typical mitochondria containing well developed cristae were observed (Plate VI, Fig. 2). The particles observed in the cells after 6 hours cultivation are thought to be primitive (Type I) and immature form of mitochondria (Type II). The number of mitochondria with cristae (Type III) increased during culture time, and it attained to maximum in grown cells after 
2 days. At that time the electron transparent particles began to appear in the cell, and some cells began to autolyse. After 30 days, almost all of the cells showed autolysis, the mitochondria were scarcely recognized and many electron transparent particles were present in normal cells.

In ultrathin section the mature mitochondria show circular or elliptical shape in outline. It is supposed that they are probably rod-shaped in the cell, about 0.2 to $0.3 \mu$ in diameter and 0.4 to $0.6 \mu$ in length. The cristae run irregularly to various direction (Plate VII, Fig. 1). The mitochondria are composed of paired membrane systems with 200 to $225 \AA$ in thickness. Inspection of the mitochondrial section in detail (Plate VII, Fig. 2) indicates that each membrane is composed of two electron-dense layers, about $25 \AA$ thick, stained with potassium permanganate solution. These layers are separated by a light space of about $25 \AA$ in thickness. Thus, total thickness of each membrane is about $75 \AA$. The electron micrographs of the mitochondrion photographed through focusing support this result. ${ }^{19)}$

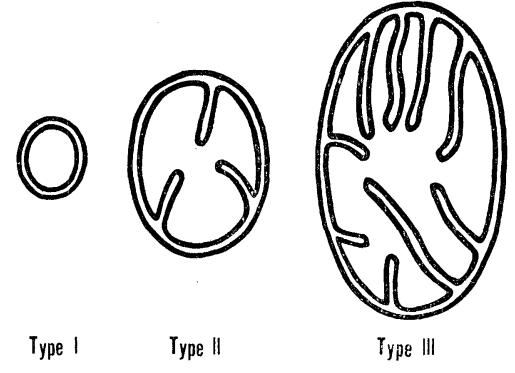

Fig. 1. Scheme of developmental stages of yeast-mitochondria. Type I, primitive mitochondrion (no cristae stage); Type II, young mitochondrion (developing cristae stage); Type III, mature mitochondrion (typical cristae stage).

Sometimes the mature mitochondrion showed a shape of dumb-bell or elongation of about $2 \mu$ in length, constricted at middle part or other part of the body (Plate VIII, Figs. 1 and 2). These figures seem to show the dividing stages of mitochondria. ${ }^{20,21}$ ) Mitochondria of this kind of shape do not appear in young cells, and mature mitochondria are supposed to multiply by division.

Relation between environment and mitochondrial formation. As shown in Table 1

Table 1. Change in frequency of appearance of cells in which three types of mitochondria appear according to growth phase and kinds of media on agar slope.

\begin{tabular}{|c|c|c|c|c|}
\hline \multirow{2}{*}{$\begin{array}{l}\text { Mitochon- } \\
\text { dria }\end{array}$} & \multirow{2}{*}{$\begin{array}{l}\text { Time } \\
\text { of } \\
\text { growth } \\
\text { (hrs) }\end{array}$} & \multicolumn{3}{|c|}{ Frequency $(\%)$} \\
\hline & & No. 1 & No. 2 & No. 3 \\
\hline \multirow{4}{*}{ Type I } & 6 & 70 & 70 & 25 \\
\hline & 12 & 57 & 11 & 0 \\
\hline & 96 & 7 & 0 & 0 \\
\hline & 168 & 0 & 0 & 0 \\
\hline \multirow{4}{*}{ Type II } & 6 & 80 & 80 & 75 \\
\hline & 12 & 43 & 33 & 70 \\
\hline & 96 & 13 & 0 & 10 \\
\hline & 168 & 20 & 0 & 0 \\
\hline \multirow{4}{*}{ Type III } & 6 & 0 & 10 & 50 \\
\hline & 12 & 80 & 100 & 100 \\
\hline & 96 & 74 & 100 & 90 \\
\hline & 168 & 40 & 0 & 67 \\
\hline
\end{tabular}

Table 2. Mean number of mitochondria per cell and frequency of appearance of each type of mitochondria in total on agar slope.

\begin{tabular}{|c|c|c|c|c|c|}
\hline \multirow{2}{*}{ Medium } & \multirow{2}{*}{$\begin{array}{l}\text { Time } \\
\text { of } \\
\text { growth } \\
\text { (hrs) }\end{array}$} & \multirow{2}{*}{$\begin{array}{l}\text { Mean } \\
\text { num- } \\
\text { ber }\end{array}$} & \multicolumn{3}{|c|}{ Frequency (\%) } \\
\hline & & & Type & $\begin{array}{c}\text { Type } \\
\text { III }\end{array}$ & $\begin{array}{c}\text { Type } \\
\text { III }\end{array}$ \\
\hline \multirow{4}{*}{ No. 1} & 6 & 3.2 & 64 & 36 & 0 \\
\hline & 12 & 4.3 & 10 & 70 & 20 \\
\hline & 96 & 4.7 & 5 & 11 & 84 \\
\hline & 168 & 1.2 & 0 & 34 & 66 \\
\hline \multirow{4}{*}{ No. 2} & 6 & 3.0 & 45 & 45 & 10 \\
\hline & 12 & 6.0 & 6 & 6 & 88 \\
\hline & 96 & 4.1 & 0 & 0 & 100 \\
\hline & 168 & 0.0 & 0 & 0 & 0 \\
\hline \multirow{4}{*}{ No. 3} & 6 & 4.5 & 25 & 50 & 25 \\
\hline & 12 & 7.0 & 0 & 20 & 80 \\
\hline & 96 & 5.7 & 0 & 3 & 97 \\
\hline & 168 & 2.7 & 0 & 0 & 100 \\
\hline
\end{tabular}


and 2 the mitochondria of Type VIII did not appear on No. 1 medium after 6 hours cultivation (Plate VI, Fig. 1), but on No. 3 medium, it was recognized in $50 \%$ of cells observed (Plate VI, Fig. 3). The mean number of mitochondria (Type I+Type II+ Type III) per cell of ultrathin section was 3.2 in the cells grown on No. 1 medium after 6 hours, but it was 4.5 on No. 3 medium. The difference of the number of mitochondria became greater with the cultivation time after 12 hours, there were 4.3 mitochondria in an average in the cells grown on No. 1, but 7.0 on No. 3 medium. (Plate VI, Figs. 2 and 4). In these mitochondria, three types of mitochondria appeared with the frequency as shown in the right part of Table 2 .

As shown in Table 3, there first appeared the mitochondria of Type I after 1 hour, the mitochondria of Type II after 2 hours, the mitochondria of Type III after 4.5 hours, in the cells grown on No. $1^{\prime}$ medium. But on No. $3^{\prime}$ medium, the appearance of all types of mitochondria was faster than that of No. 1' medium: there were the mitochondria of Type I after 0.5 hours, the Types II and III after 1 hours. On the other hand, on No. 5 medium, the mitochondria of Type I appeared after

Table 3. Change in frequency of appearance of cells in which three types of mitochondria appear according to growth phase and kinds of liquid medium.

\begin{tabular}{|c|c|c|c|c|c|}
\hline \multirow{2}{*}{$\begin{array}{l}\text { Mitochon- } \\
\text { dria }\end{array}$} & \multirow{2}{*}{$\begin{array}{l}\text { Time } \\
\text { of } \\
\text { growth } \\
\text { (hrs) }\end{array}$} & \multicolumn{4}{|c|}{ Frequency $(\%)$} \\
\hline & & No. $1^{\prime}$ & No. 3 & No. 4 & No. 5 \\
\hline \multirow{5}{*}{ Type I } & 0.5 & 0 & 10 & 0 & 14 \\
\hline & 1.0 & 78 & 100 & 66 & 32 \\
\hline & 2.0 & 36 & 72 & 33 & 50 \\
\hline & 4.5 & 33 & 25 & 20 & 33 \\
\hline & 24.0 & 7 & 5 & 6 & 0 \\
\hline \multirow{5}{*}{ Type II } & 0.5 & 0 & 0 & 0 & 0 \\
\hline & 1.0 & 0 & 50 & 0 & 37 \\
\hline & 2.0 & 80 & 43 & 100 & 88 \\
\hline & 4.5 & 65 & 100 & 80 & 30 \\
\hline & 24.0 & 45 & 80 & 10 & 10 \\
\hline \multirow{5}{*}{ Type III } & 0.5 & 0 & 0 & 0 & 0 \\
\hline & 1.0 & 0 & 50 & 0 & 20 \\
\hline & 2.0 & 0 & 90 & 9 & 43 \\
\hline & 4.5 & 50 & 100 & 30 & 60 \\
\hline & 24.0 & 93 & 100 & 100 & 100 \\
\hline
\end{tabular}

Table 4. Mean number of mitochondria in one cell and frequency of appearance of each type of mitochondria in total on agar slope.

\begin{tabular}{|c|c|c|c|c|c|}
\hline \multirow[b]{2}{*}{ Medium } & \multirow{2}{*}{$\begin{array}{l}\text { Time } \\
\text { of } \\
\text { growth } \\
\text { (hrs) }\end{array}$} & \multirow{2}{*}{$\begin{array}{l}\text { Mean } \\
\text { num- } \\
\text { ber }\end{array}$} & \multicolumn{3}{|c|}{ Frequency $(\%)$} \\
\hline & & & Type & $\begin{array}{c}\text { Type } \\
\text { II }\end{array}$ & $\begin{array}{c}\text { Type } \\
\text { III }\end{array}$ \\
\hline \multirow{5}{*}{ No. $1^{\prime}$} & 0.5 & 0.0 & $\ldots$ & - & - \\
\hline & 1.0 & 3.7 & 100 & 0 & 0 \\
\hline & 2.0 & 4.9 & 64 & 36 & 0 \\
\hline & 4.5 & 8.0 & 57 & 35 & 8 \\
\hline & 24.0 & 4.4 & 3 & 31 & 66 \\
\hline \multirow{5}{*}{ No. $3^{\prime}$} & 0.5 & 3.0 & 100 & 0 & 0 \\
\hline & 1.0 & 4.0 & 79 & 14 & 7 \\
\hline & 2.0 & 7.9 & 9 & 67 & 24 \\
\hline & 4.5 & 8.5 & 5 & 20 & 75 \\
\hline & 24.0 & 5.3 & 2 & 5 & 97 \\
\hline \multirow{5}{*}{ No. 4} & 0.5 & 0.0 & - & - & - \\
\hline & 1.0 & 3.2 & 100 & 0 & 0 \\
\hline & 2.0 & 5.9 & 12 & 86 & 2 \\
\hline & 4.5 & 8.0 & 10 & 80 & 10 \\
\hline & 24.0 & 4.5 & 1 & 27 & 72 \\
\hline \multirow{5}{*}{ No. 5} & 0.5 & 3.5 & 100 & 0 & 0 \\
\hline & 1.0 & 4.0 & 60 & 30 & 10 \\
\hline & 2.0 & 4.4 & 58 & 22 & 20 \\
\hline & 4.5 & 8.6 & 8 & 9 & 83 \\
\hline & 24.0 & 5.0 & 0 & 5 & 95 \\
\hline
\end{tabular}

0.5 hours, and Types II and III after 1 hour. These results show the shorter time than the result of the case of No. 4 medium. The mean number of mitochondria per cell of ultrathin section and frequency of each mitochondria in total mitochondria also show clearly the influence of medium as shown in Table 4. 
In the anaerobically grown cells, the fine structures of the cell wall, cytoplasmic membrane (cell membrane) and nucleus were normal. The nuclear membrane and vacuolar membrane existed, but, mitochondria were not recognized in these cells, and ERS scarcely existed in cytoplasm (Plate IX, Fig. 1). There were degenerative mitochondria and ERS in 10\% of cells which grew in ergosterol-containing completesynthetic medium (Plate IX, Fig. 2).

Origin of yeast-mitochondria. To pursue the origin of mitochondria, the yeast-cells were cultured for a short time in liquid medium in aerobic condition after the confirmation of disappearance of mitochondria by means of anaerobic culture. The relation between the growth phase and the fine structure of the yeast-cells is shown in Table 5 and Plate IX, Figs. 3 and 4 . At 0.5 hour's aerobic growth, mitochondria did not exist, but ERS distributed numerously in cytoplasm. There were variations of length of the membrane-structure of ERS, the shortest was $0.1 \mu$, and the longest one was $4 \mu$. In the secondary phase, the ERS and the mitochondria of Type I appeared at the same time in cytoplasm. The smallest diameter of Type I was $0.05-0.08 \mu$, and the biggest was $0.3 \mu$. After then, the mitochondria of Types II and III appeared, and ERS gradually disappeared.

Table 5. Appearance of endoplasmic reticulumlike structure (ERS) and three types of mitochondria according to growth phase.

\begin{tabular}{c|c|c|c|c|}
\hline \multirow{2}{*}{$\begin{array}{c}\text { Time of } \\
\text { growth (hrs) }\end{array}$} & ERS & \multicolumn{3}{|c}{ Mitochondria } \\
\cline { 2 - 5 } & & Type I & Type II & Type III \\
\hline 0.5 & H & - & - & - \\
1.0 & HHt & + & - & - \\
2.0 & H & \# & + & - \\
4.5 & H & + & + & H \\
24.0 & + & - & + & H \\
\hline
\end{tabular}

Anaerobically grown cells did not have any activity of oxygen-absorption. After 1 hour's aeration, the cells recovered the activity in $58.2 \%$ of the activity of the cells which were grown for 24 hours. After 2 hours' aeration, the activity increased to $65.6 \%$. This results supported the above mentioned results of electron microscopy, that is to say, the burst of respiratory activity in the first 1 or 2 hours parallels of ERS and mitochondria.

Yeast-cells in glucose-phosphate buffer ( $\mathrm{pH}$ 7.4) were disrupted in French Press at $600 \mathrm{~kg} / \mathrm{cm}^{2}$. The suspension was centrifuged for 5 minutes at $3,000 \mathrm{rpm}$ to remove cell-walls and undisrupted cells. The cytochrome $\mathrm{C}: \mathrm{O}_{2}$ oxidoreductase activity of the supernatant was measured. All manipulations were carried out at $0^{\circ}$. Cytochrome $\mathrm{C}: \mathrm{O}_{2}$ oxidoreductase activity was measured by a decrease in absorption at $550 \mathrm{~m} \mu$ of cytochrome reduced with ascorbate at $30^{\circ}$ with the method of Minnaert. ${ }^{22}$ The absorption spectrum of the aerated cells showed the increase of activity little more than that of the anaerobically grown cells, as judged by Soret region.

Furthermore, some electron micrographs seemed to show the intimate relation between the ERS and mitochondria. Some ERSs rolled up at their both ends (Plate VIII, Fig. 4) and they look like the membrane of mitochondria. Fig. 3 in Plate VIII showsERS resembled the membrane of a mitochondria. On the other hand, any electron micrograph which shows the nuclear origin of mitochondria could not be obtained. ${ }^{20}$

\section{Discussion}

On the base of the present experiments, the author has classified three developmental stages of yeast-mitochondria and propose to call these three stages as primitive, 
young, and mature types of mitochondria.

Yeast-mitochondria are surrounded by two membranes, and each membrane, $75 \AA$ in thickness, is composed of two thin layers separated by light space of $25 \AA$. Therefore they agree with the unit membranes proposed by Robertson. ${ }^{23}$

In the present studies, when the concentration of glucose decreases and ethanol was added in the medium as carbon source, the formation of mitochondria was promoted. At low concentration of glucose, glucose is consumed quickly by glycolysis, and using metabolism changes to TCA cycle by using ethanol as carbon source, and at that time the formation of mitochondria is promoted. Ethanol is used instead of glucose as carbon source, and energy is derived from respiration immediately, so the formation of mitochondria is promoted more rapidly.

The existence of mitochondria was not recognized in anaerobically grown cells, and the ERS along inside of the cytoplasmic membrane or inner part of the cytoplasm also disappeared. But there were some ERS, and degenerative mitochondria were observed in $10 \%$ cells grown anaerobically added by ergosterol and oleic acid which is included in Tween 80 , while in the other $90 \%$ cells they did not appear. These results suggest that the formation of mitochondria or membrane is not achieved only by the presence of ergosterol, and oxygen may be required to make the ability of ergosterol active, and that it may be more necessary to produce some substances under the presence of oxygen. Therefore, the formation of mitochondria would be controlled by the character of carbon source in substrate, the presence of oxygen and essential substances.

It was confirmed that in the early stage of aerobically grown cells, numerous ERSs were present in cytoplasm before the formation of mitochondria, and there was an inverse relation between this structure and formation of mitochondria. These membranes had also the same double units membranes structure. ${ }^{23}$ There seems to exist a close relation between the origin of mitochondria and ERS. If a membrane of ERS rolls and elaborately folds each other, the membrane is able to change to a shape of ball or an ellipsoid body. After then, by infolding, mitochondrion-like body is formed.

The categories which have been proposed by various authors as to the origin of mitochondria may be classified into the following three categories: 1. growth and division of preexisting mitochondria, ${ }^{24)} 2$. elaborate folding of preexisting membrane, ${ }^{25}$ ) 3. de novo synthesis from submicroscopic precursors present in the cytoplasm. ${ }^{26)}$ The case of yeast-mitochondria may belong to the formation from membrane, and ERS may be thought as the origin of mitochondria. A membrane of ERS may differentiate to mitochondria with the supply of protein and lipid which are synthesized under the control of structural DNA in cytoplasm. However, further experiments should be done for the solution of the problem whether some precursors which induce such biogenesis exist in the cell or not.

On the other hand, it has been recently reported that specific granules exist in mitochondria in the cells of toad urinary bladder and rat kidney. ${ }^{27)}$ It has been also confirmed that there is DNA in mitochondria in the cell of chicken embryo ${ }^{28,29)}$ and that DNA exists in mitochondria of Pteridium qauilium by means of autoradiography. ${ }^{30}$ ) In baker's yeast, it has been reported that the preparation of mitochondria purified by flotation in density gradients contains a significant quantity of DNA. ${ }^{31}$ The isolation of DNA from mitochondria of Neurospora crassa has also been stated, ${ }^{32}$ 
The author observed some special structure in the immature form of mitochondria as similar to the DNA-structure proposed by Nass (Osumi, M., unpublished), and this structure seems to relate with mitochondrial formation. Autoradiographical method would be useful to make these problems clear, and it is necessary to analyze them by biochemical and cytochemical methods as well as electron microscopy.

\section{Summary}

The influence of different composition of medium on the formation of mitochondria, the developmental process and the origin of mitochondria were studied by electron microscopy in the cell of Saccharomyces Strain No. 24843 (Lindegren's Carbondale Breeding Stock). The formation of mitochondria in aerobically grown yeast is more promoted by ethanol than by glucose as carbon source, and it is also promoted by adding ergosterol to the medium. The mitochondria and endoplasmic reticulum-like structure disappear in anaerobically grown yeast, but they still exist in $10 \%$ of cells which have grown on the medium with ergosterol.

The yeast-mitochondria are enveloped by a pair of unit membranes. The total thickness of the mitochondrial membrane is 200 to $225 \AA$. The unit membrane is about $75 \AA$ thick and is made up of the two electron-opaque layers, each about $25 \AA$ thick, separated by a light space of the same thickness.

The origin of yeast-mitochondria is supposed to have an intimate relation with the membrane of endoplasmic reticulum-like structure. This kind of membrane is supposed to roll up and elaborately fold each other. The inner membrane infold from some parts into the matrix, and form typical mitochondrial cristae. Then mature mitochondria are formed.

\section{Acknowledgements}

The author wishes to express her sincere thanks to Dr. Akira Yuasa, Professor of University of Tokyo, for his continuous guidance throughout this work. Thanks are also due to Dr. Sitiro Sato, University of Tokyo, and Dr. Akira Tanaka, Head of Second Application Research of Japan Electron Optic Co. Ltd., for permiting her to use equipments in their laboratories. The author is indebted to Dr. Nobundo Sando, University of Tokyo, for his support in biochemical measurements and his encouragement on this work.

\section{References}

1) Fernández-Morán, H., Circulation, 26: 1039 (1962). $\quad$ 2) Parsons, D. F., Science, 140: 985 (1963). 3) Chance, B., Science, 142: 1176 (1963). 4) Fernández-Morán, H., Oda, T., Blair, P. V., and Green, D. E., J. Cell Biol. 22: 61 (1964). 5) Oda, T., and Nishi, Y., J. Electronmicroscopy, 12: 290 (1964). 6) Green, D. E., Scientific American, 212: 63 (1964). 7) Stasny, J. T., and Crane, F. L., J. Cell Biol. 22: 49 (1964). 8) Lehninger, A. L., The Mitochondrion (W.A. Benjamin, Inc., New York, 1964). 9) Linnane, A. W., Vitols, E., and Nowland, P. G., J. Cell Biol. 13: 345 (1962). 10) Yotsuyanagi, Y., J. Ultrastr. Res. 7: 121 (1962). 11) Yotsuyanagi, Y., ibid. 7: 141 (1962). 12) Morpurgo, G., Serlupi-Crescenzi, G., Tecce, G., Valente, F., and Venettacci, D., Nature, 201: 897 (1964). 13) Wallace, P. G., and Linnane, A. W., Nature, 201: 1191 (1964). 14) Polakis, E. S., Bartley, W., and Meek, G. A., Biochem. J. 90: 369 (1964). 15) Sugimura, T., Okabe, K. and Rudney, H., Biochim, Biophys. Acta, 82: 350 (1964). 16) Yumoto, S., and Wakabayashi, K. J. Electronmicroscopy, 12: 274 (1964). 17) Gibor, A. and Granick, S., Science, 145: 890 (1964). 18) Sando, N., J. Gen. Appl. Microbiol, 9: 233 (1963). 19) Osumi, M. Jap. Women's Univ. Jour. 12: 49 (9165). 20) Bell. 
P. R., and Mühlethaler, K., J. Cell Biol. 20: 235 (1964). 21) Elliott, A. M., and Bak. I. J., J. Cell Biol. 20: 113 (1964). 22) Minnaert, K., Biochim. Biophys. Acta. 50: 23 (1961). 23) Robertson, J. D., Biochem. Soc. Symp. (Cambridge) 16: 3 (1959). 24) Luck, D. J. L., Proc. Natl. Acad. Sci. U.S. A. 49: 233 (1963). 25) Robertson, J. D. Regional Neurochem. Proc. 4th Neurochem. Symp. 497 (Pergamon, Oxford, 1961). 26) Berger E. R., J. Ultrastr. Res. 11: 90 (1964). $\quad 27)$ Peachey, L., J. Cell Biol. 20: 95 (1964). 28) Nass, M. M. K., and Nass, S., J. Cell Biol. 19593 (1963). $\quad$ 29) Nass, M. M. K., and Nass, S., ibid. 19: 613 (1963). 30) Bell, P. R. and Mühlethauler, K., J. Mol. Biol. 8: 853 (1964). 31) Schatz G., Halsbrunner, E. and Tuppy, H., Biochem. Biophys. Res. Comm. 15: 127 (1964). 32) Luck, D. J. L., and Reich, E., Proc. Natl. Acad. Sci. U. S. A. 52: 931 (1964).

摘要

\section{大隅正子：コウボキンーミトコンドリアの形成に関する電子顕微鏡的研究}

コウボキン Saccharomyces 属の haploid 株, No. 24843 (Lindegren's Carbondale Breeding Stock) を用いて, ミトコンドリアの形成に扑る培地組成の影響, 発達過程, ミトコンドリアの膜構造, および ミトコンドリアの起原を, 電子顕微鏡によって追求した。

ミトコンドリアの形成は，炭素源としては glucose よりも ethanol によって促進される。 また， ergosterol を培地に添加すると形成は促進される。辌気培養するとミトコンドリアやER(小胞体)様構造は 消失する。しかし ergosterol を添加した培地で生育された場合は, 総数の $10 \%$ の細胞中に，くずれた形の ミトコンドリアや，棈造のうえでERに似た膜構造が存在する.

ミトコンドリアの発達過程を, クリステの状態から, クリステの采だ形成されていない原始形ミトュン ドリア (primitive mitochondria)クリステの出来はじめた奻形ミトコンドリア (young mitochondria), クリ ステが完成した成熟形ミトコンドリア (mature mitochondria) の三種類に分類した.

ミトュンドリアの膜は, 二重のュニット膜から出来ている。ユニット膜は約 $75 \AA \AA$ の厚さで, 約 $25 \AA ̊$ の二枚 の薄い膜が，約 $25 \AA ̊$ の間隔を执いて対になっている。 このユニット膜が二枚重って，全体の厚さは約 $200 〜$ 225Åになる。.

コウボキン細胞のミトコンドリアの起原とER様構造の膜とは，関係が深いと考学られる，この膜がまく ようになり, 膜の端が接合されて, 球状むたは情円体となり(原始形ミトコンドリア), その内膜が内側に落 ちこんでクリステを形成しはじめ(幼形ミトコンドリア), さらにクリステが発達して, 成熟形ミトコンドリ アへと発達すると考兄れる。ささらに，生化学的な検討を行ないこれを裏つける結果を得た。この際，膜 構造にこのような変化を抗こさせる基体があるかどうかについては，さらに検討を要する。（日本女子大学 生物学教室)

\section{EXPLANATION OF PLATES}

Key to abbreviations:

$\mathrm{CM}$, cytoplasmic membrane

$\mathrm{CW}$, cell wall

Cyt, cytoplasm

$\mathrm{DM}$, dividision-like mitochondrion

ER, endoplasmic reticulum-like structure

$\mathrm{M}$, mitochondrion

MM, mitochondrial membrane

MC, mitochondrial cristae
$\mathrm{N}$, nucleus
NM, nuclear membrane
$\mathrm{NP}$, nuclear pore
$\mathrm{PM}$, primtive mitochondrion
$\mathrm{V}$, vacuole
VM, vacuoler membrane
YM, young mitochondrion

In all figures the length of the black line represents $0.5 \mu$, unless otherwise indicated.

\section{PLATE VI}

Fig. 1. Aerobically grown cell after $6 \mathrm{hrs}$. cultivation on $2 \%$ glucose-agar medium. These are some primitive mitochondria which showdouble membranes and a young mitochondrion. $\times 35,000$. Fig. 2, Aerobically grown cell after $12 \mathrm{hrs}$. cultivation on $2 \%$ glucose-agar medium. Numerous 



OsumI, M.: Electron Microscopical Observations on the Formation of Yeast-mitochondria. 


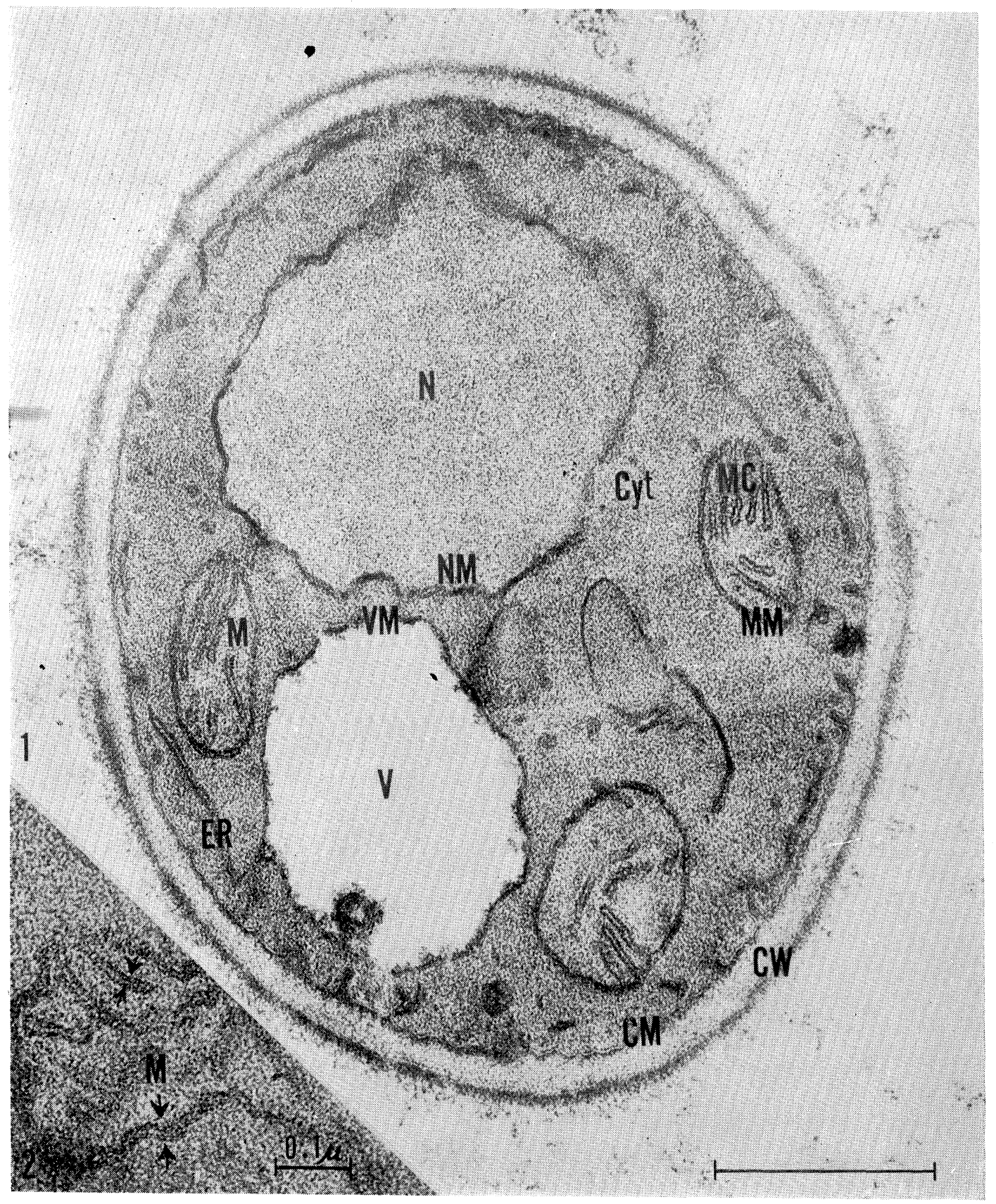

Osumi, M.: Electron Microscopical Observations on the Formation of Yeast-mitochondria. 

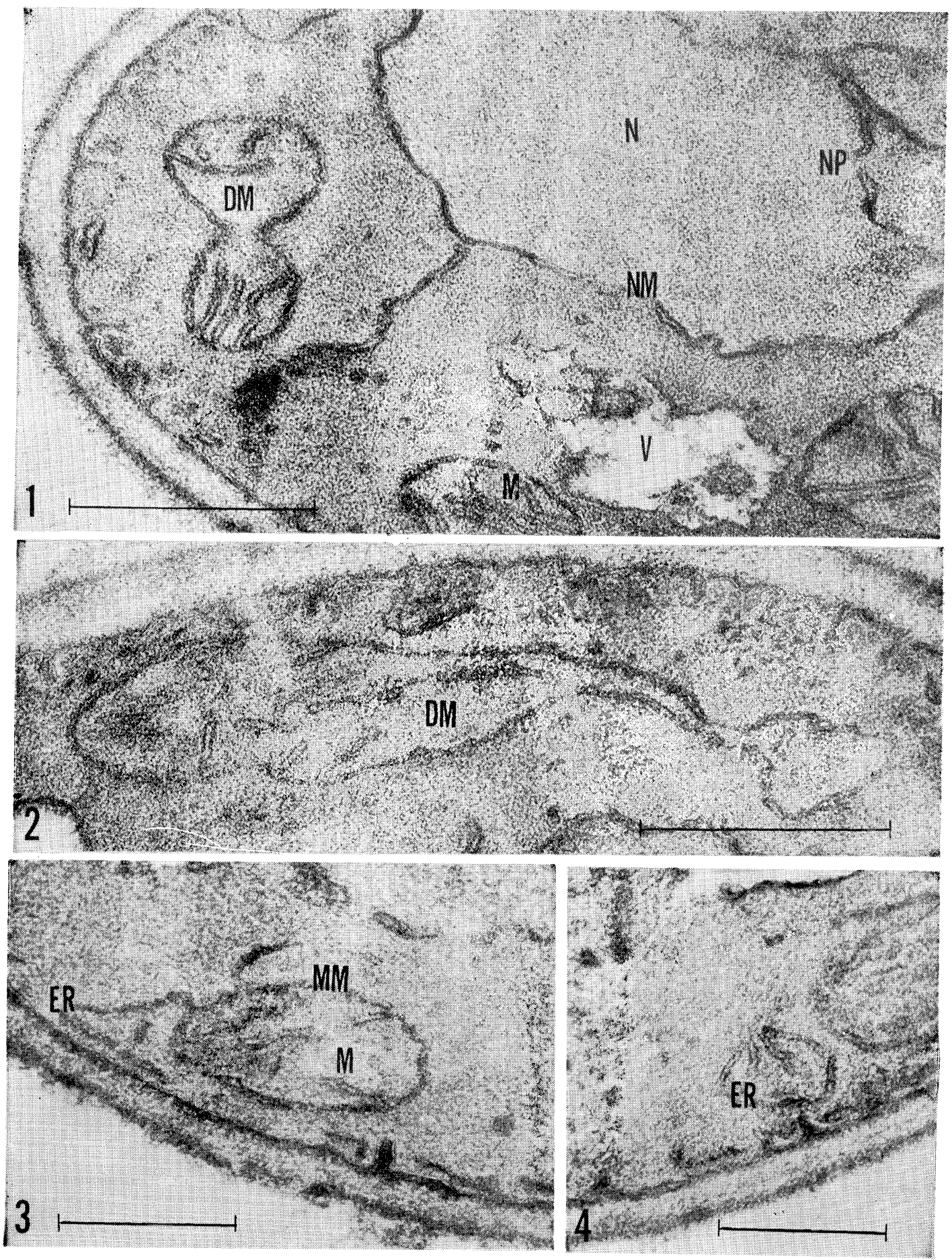

Osumi, M.: Electron Microscopical Observations on the Formation of Yeast-mitochondria. 

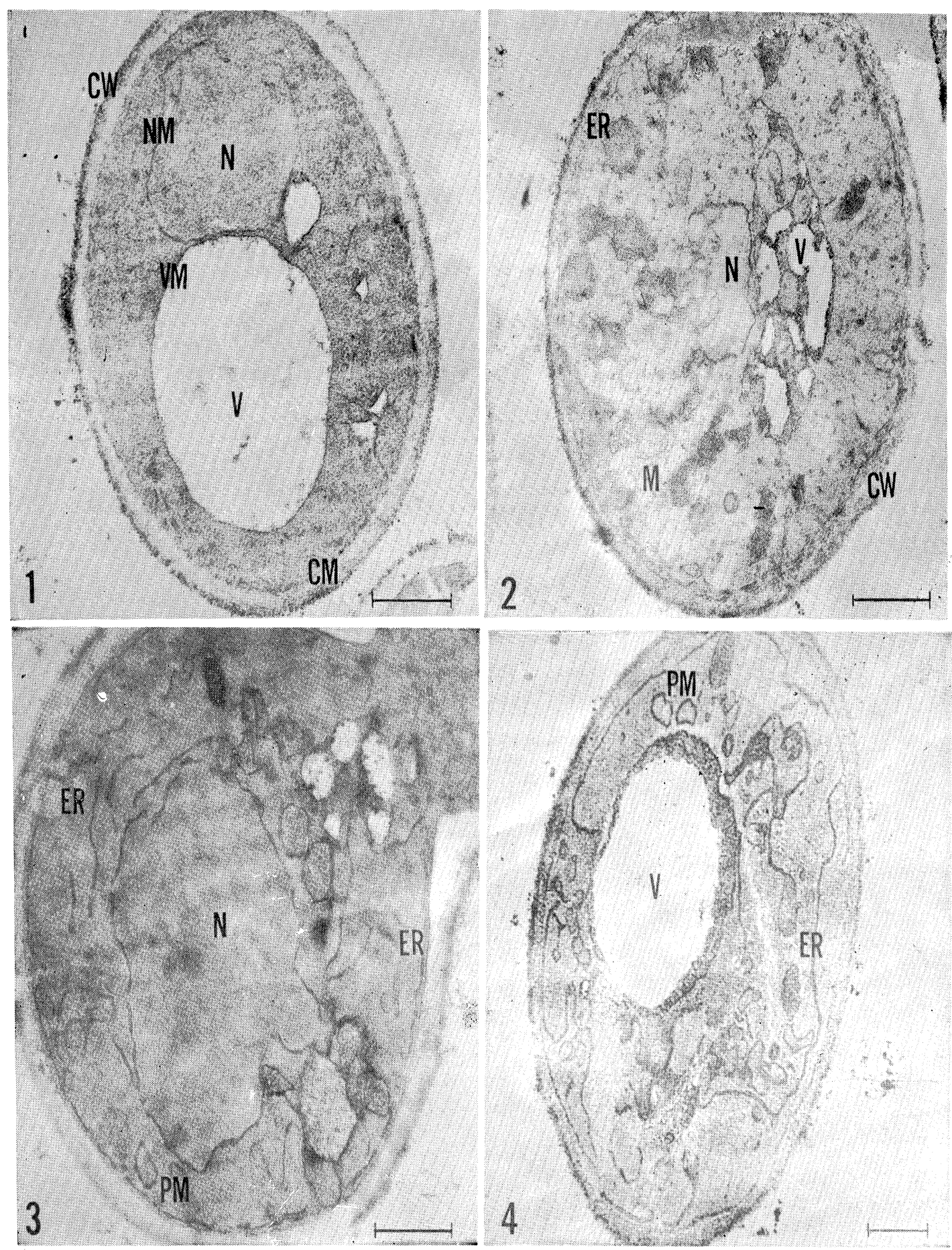

OsumI, M.: Electron Microscopical Observations on the Formation of Yeast-mitochondria. 
young mitochondria are appearing. $\times 40,000$. Fig. 3 . Aerobically grown cell after 6 hrs. cultivation on $2 \%$ ethanol-agar medium. Young and mature mitochondria are seen. $\quad \times 40,000$. Fig. 4. Aerobically grown cell after $12 \mathrm{hrs}$. cultivation on $2 \%$ ethanol-agar medium. There are numerous mature mitochondria in the cell. $\times 40,000$.

\section{PLATE VII}

Fig. 1. Section through a resting yeast cell, showing cell wall, cytoplasmic membrane, nucleus, vacuole, mitochondrion, endoplasmic reticulum-like structure. $\times 63,000$. Fig. 2 . A high magnification of the fine structure of a part of mitochondrion. The mitochondrial membrane is composed of double units membrane (arrow). $\times 105,000$.

\section{PLATE VIII}

Fig. 1. Mitochondrion-profile, showing type of division. It usually divides into two daughter mitochondria. Mature mitochondrion divides at the middle portion. $\times 74,000$. Fig. 2 . Sometimes mitochondrion elongates about 2 times or more of normal length, and it constricts into two mitochondria. $\times 74,000$. Fig. 3. Sometimes mitochondrial membrane connects with endoplasmic reticulum-like structure. $\times 50,000$. Fig. 4. Endoplasmic reticulum-like structure is going to fold innerward elaborately. $\times 50,000$.

\section{PLATE IX}

Fig. 1. Section through an anaerobically grown cell. No mitochondria and endoplasmic reticulum-like structure are seen in cytoplasm, but the other organelles still exist normaly. $\times 23,000$. Fig. 2 . Section through an anaerobically grown cell in complete-synthetic medium which contains ergosterol. These are degenerated mitochondria and endoplasmic reticulum-like structure. $\times 23,000$. Fig. 3. Aerobically grown cell after $1 \mathrm{hr}$. aeration. There are numerous endoplasmic reticulum-like'structures in the cell. $\times 23,000$. Fig. 4 . Aerobically grown cell cfter 2 hrs. aeration. There are various sizes of the primitive mitochondria in the cell. $\times 18,000$. 